\title{
Can Fraud Triangle Model Predict Fraudulent Financial Statements? Evidence from Egypt
}

\section{Shaimaa Fikry Mehanna}

\author{
Assistant professor of accounting \\ Zagazig university
}

Mohammed Mahmoud Soliman

Assistant professor of accounting

Zagazig university

\section{Abstract :}

Purpose - The aim of this study is to examine the risk factors of the fraud triangle model, the core of fraud auditing standards, to assessing probability of engaging in fraudulent financial statements.

Design/Method - Depending on logistic regression analysis, this study examined the impact of the elements of fraud triangle model on the detection of financial frauds in financial statements. Significant variables, relating to pressure, opportunity and rationalization are investigated.

Findings - this study found that fraud risk factors for pressure (financial leverage and sales to total assets), for opportunity (independence of audit committee), and for rationalization (total accruals) are significantly associated to the occurrence of fraudulent financial statements.

Key words: Fraud Triangle Model, Pressure, Opportunity, Rationalization, SAS 99. Paper type Research paper

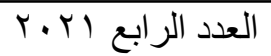




\section{INTRODUCTION :}

In last decades, business community was disturbed by considerable corporate financial frauds; Xerox, Enron, Qwest, WorldCom, and Global Crossing are just five companies that dissipated billions of dollars and daunted public confidence (Suyanto, 2009). The respective losses of the five companies' market capitalization exceed $\$ 450$ billion dollars (Suyanto, 2009). These and subsequent corporate financial frauds have raised public concerns regarding the reliability of financial reporting (Persons, 1995; Aghghaleh et al, 2014). The public concerns regarding the fraudulent financial reporting have fostered the issuance of new auditing standards and other regulations that concentrated on detecting and preventing such frauds (Lou and Wang, 2009; Suyanto, 2009).

In 1988, Statement on Auditing Standards No. 53 was issued by American Institute of Certified Public Accountants concentrated on the auditor's responsibility in planning and performing his examination to detect material errors and irregularities which affecting financial reporting (Persons, 1995; Lou and Wang, 2009). Then, in 1997, SAS No. 82 was issued to provide more comprehensive guidance to help auditors detecting frauds in financial statements by focusing on areas of high risk compared to SAS No.53 (Lou and Wang, 2009; Aghghaleh et al, 2014). In 2002, SAS No. 82 was superseded by SAS No. 99 focusing on improving 
the efficiency of auditors in detecting frauds in financial statements by assessing the fraud risk factors (Aghghaleh et al, 2014). Additionally, in 2002, the International Auditing and Assurance Standards Board established the International Standards on Auditing No. 240 concentrated on auditors' responsibility to detect frauds in financial statements (Lou and Wang, 2009).

The fraud risk factors illustrated in fraud standards SAS No. 99 and ISA No. 240 were based on fraud triangle model proposed by D. R. Cressey in 1953 (Lou and Wang, 2009; Aghghaleh et al, 2014). In this model, Cressy categorized the fraud risk factors into three groups; pressure (incentive or motivation), opportunity, and rationalization (attitude) (Lou and Wang, 2009; Aghghaleh et al, 2014). Cressy's argues that when the three risk factors -pressure, opportunity, and rationalization- coexist, financial fraud will happen (Nakashima, 2017). In 2002, American Institute of Certified Public Accountants adopted the fraud triangle model and introduced it in SAS No. 99. AICPA claimed that only the existence of one fraud risk factor is needed for the occurrence of financial frauds (Suyanto, 2009).

This study intends to recognize the three fraud risk factors -pressure, opportunity, and rationalization- that presented in SAS No. 99, and empirically relates the existence of these factors to occurrence of financial frauds by making use of not only several financial ratios- capturing firm's characteristics relating

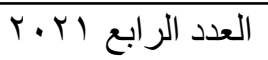

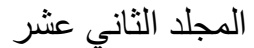


to the pressure and rationalization dimensions of fraud triangle model- but also several internal corporate governance mechanisms - capturing firm's quality of corporate governance practices that representing the opportunity dimension of fraud triangle model- for predicting financial statements frauds. Fraud triangle model is not supported by enough empirical evidence in the Egyptian setting. Therefore, urgent studies are needed to identify the fraud mechanism and to predict and detect fraudulent financial statements. This is the primary motivation of the study.

In this study, we investigate whether the fraud triangle model relates to financial statement frauds based on three proposed axes; First, we identify proxy variables relating to each risk factor/component of the fraud triangle model -pressure, opportunity, and rationalization- based on prior literature. Second, each risk factor/component of the fraud triangle is investigated separately before combining them. Third, we conducted and test our models to predict and detect financial statement frauds for the potential benefits of not only investors and creditors but also auditors.

This study contributes to the literature in two ways; First, the study presenting its results concerning the effectiveness of fraud triangle model in detecting financial statements frauds using Egyptian public firm data. Since majority of prior literature concerning financial statement frauds prediction had employed

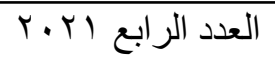

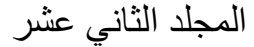


data from the developed markets especially USA, France, and Japan; the present study will extend this issue to the Egyptian's setting. Second, this study provides its results by making use of not only financial statement ratios but also corporate governance mechanisms for predicting financial statements frauds.

The rest of this study will be organized as follows. Section 2 presents brief review of prior literature and the development of study's hypotheses. Sections 3 describes data and methodology. Sections 4 discusses the main results of empirical analysis. The final section highlights the study's conclusion.

\section{LITERATURE REVIEW AND HYPOTHESES DEVELOPMENT}

Detecting financial frauds have become a basic concern of many researchers and academics, the matter that motivated them to make myriad of empirical studies. In this context, the fraud triangle model is considered a well-recognized technique used in predicting fraud occurrence, which in turn, had fostered AICPA, in 2002, to adopt the fraud triangle model - which was introduced by D. R. Cressey in 1953- and further introduced it in SAS No. 99. (Suyanto, 2009).

AICPA defines financial statement fraud, in SAS No. 99, as a deliberate or intentional act or omission results in material

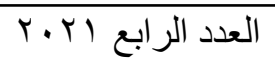

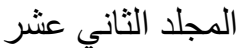


misstatements in financial statements -the subject of the audit ${ }^{(1)}$ (Suyanto, 2009; Manurung and Hadian, 2013; Nakashima, 2017). Fraud is a deliberate act by a company's management that involve the use of deception to gain unlawful profits (Meiryani, 2020). According to SAS No. 99, fraudulent financial reporting results from intentional misstatements or elimination of monetary amounts and disclosures in financial reports with the purpose of deceiving external users of financial reports, ignoring critical financial information, and breaching the generally accepted accounting principles (GAAP) (Latshaw and Elifoglu, 2003; Suyanto, 2009). Meiryani (2020) argues that fraud will occur if there are no strict prevention and detection techniques.

SAS No. 99 stipulates that the auditor is responsible for planning and performing his audit to obtain reasonable assurance about the fairness of financial statements and whether they are free of material misstatements, either caused by fraud or error (Latshaw and Elifoglu, 2003; Nakashima, 2017). On the other side, management, with those who are responsible for oversighting financial reporting process -board of directors, audit committee, board of trustees- should maintain the proper tone; create a culture of

1 - SAS No. 99 stipulates two types of material misstatements relating to auditor's consideration of financial frauds: (1) material misstatement resulting from frauds in financial reporting and (2) material misstatement resulting from misappropriation of company's assets (Suyanto, 2009). This study focuses on frauds in financial reporting.

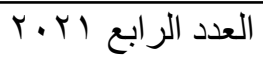

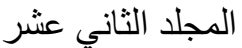


loyalty and honesty and maintain high ethical/moral standards; and built-up proper controls for fraud prevention and detection (Latshaw and Elifoglu, 2003; Nakashima, 2017).

As stated earlier, AICPA has adopted the fraud triangle model - which was proposed by D. R. Cressey in 1953 who suggested that frauds in financial reporting is caused by three risk factors; pressure, opportunity, and rationalization - then, AICPA introduced it in SAS No. 99 in 2002 (Nakashima, 2017; Fitri et al, 2019). SAS No. 99 introduces the following interpretation for the fraud risk factors of fraud triangle based on Cressey's model as follows (Latshaw and Elifoglu, 2003; Nakashima, 2017):

Three conditions are generally coexisted when fraud occurs, according to SAS No. 99; First, managers have incentives or being under pressure to commit frauds. Second, ineffective or absence of internal controls, or managers' ability to override controls which provide the opportunity for fraud perpetration. Third, management or those who are involved have the attitude that allow them to rationalize conducting a fraudulent action.

The preceding three conditions that delineated in SAS No. 99 are displayed in fraudulent behaviors as follows (Suyanto, 2009):

a. Pressure: pressure is considered the strongest motivation among the risk factors of fraud triangle (Fitri et al, 2019). It constitutes from incentives that hold managers to act in a certain manner (Suyanto, 2009). These incentives may direct 
managers to manipulate earnings to make earnings look better than reality (Lou and Wang, 2009; Fitri et al, 2019). Suyanto (2009) argued that managers under pressure have higher probability for committing financial fraud.

b. Opportunities: opportunities reflect certain circumstances that provide the chance to preparate financial frauds (Lou and Wang, 2009). Opportunities are resulting from circumstances - such as ineffective or absence of controls or management's ability to override internal controls - that provides the chance to commit fraud (Suyanto, 2009). Manurung and Hadian (2013) argued that opportunity is created by weak internal control system.

c. Rationalization: Attitude is what leads management or those who are responsible to rationalize committing fraud (Lou and Wang, 2009). Those who are involved in committing financial statement fraud can justify fraudulent behavior as being consistent with their ethical values (Suyanto, 2009). Rationalization is considered the most difficult risk factor of fraud triangle to measure (Manurung and Hadian, 2013).

The preceding risk factors of fraud triangle model, as they were introduced by SAS No. 99, will be used to develop the study hypotheses. Hence, this study, empirically, will hypothesize that the risk components of fraud triangle modelpressure, opportunity, and rationalization - are associated with higher probability of frauds in financial reporting. 


\section{FRAUD $=f($ Pressure, Opportunity, Rationalization $)$}

Each risk factor of the fraud triangle model will be proxied by its related variables. Hence, the study used the following variables:

\subsection{Proxies for Pressure Risk Factor}

Suyanto (2009) argues that financial ratios are considered a useful tool for fraud detection in financial reporting. As suggested by SAS No. 99, financial ratio is considered one of the basic analytical procedures that derived from a company's financial and operational data that help auditor to detect frauds (Latshaw and Elifoglu, 2003). Suyanto (2009) also argues that unusual or unexpected changes in financial ratios provide an indication to the probability of fraudulent activities that may carried out by company's managers. Financial ratios that will be utilized by this study include financial leverage, liquidity, profitability, and capital turnover which will be used as proxies for the pressure risk factor. This study hypothesize that the preceding financial ratios are significantly associated with the probability of fraud occurrences in financial reporting. 


\section{Financial Leverage}

Financial distress provides a firm manager an incentive to commit fraud (Suyanto, 2009). Pearsons (1995) suggested that higher financial leverage ratio is correlated with higher probability of loan agreement violation and lower ability to obtain additional debt through borrowing. Kirkos et al. (2007) argued that firms with high debt structure are more likely to be engaged in fraudulent financial statements and shifts the risk form shareholders to creditors. Hence, managers tend to manipulate earnings to meet the requirements of debt covenants (Kirkos et al. 2007). In this context, Amara et al. (2013) stated that firms whose leverage ratio is significantly high are more likely to act in illegal manner.

This study uses debt ratio (total liability/total assets) as a proxy for external pressure. Using debt ratio as a measure of financial leverage is widely employed in prior literature as an indicator for closeness to debt covenants (Lou and Wang, 2009; Manurung and Hadian, 2013). Therefore, sign of this variable is expected to be positive. We hypothesize a positively and statistically significant relationship between debt ratio and fraudulent financial reporting occurrence. Taking into consideration prior literature, we propose the first hypothesis as follows: 
H1: High leverage ratio increases the tendency toward engaging in fraudulent financial statements

\section{Liquidity}

Pearsons (1995) argued that firms with lower liquidity ratios have higher incentives to engage in committing financial frauds. Kirkos et al. (2007) and Amara et al. (2013) argued that firm with liquidity problems are more likely to engage in fraudulent financial statements than other firms. Therefore, to portray a good picture of company's liquidity situation, managers may overestimate the value of company's assets or reevaluate the value of some liabilities.

This study uses (current assets/current liabilities) as a proxy for liquidity position. Sign of this variable is expected to be negative. We hypothesize an inverse and statistically significant relationship between liquidity ratio and fraudulent financial reporting. Thus, we propose the following hypothesis.

H1 ${ }_{I I}$ : Low liquidity ratio increases the tendency toward engaging in fraudulent financial statements

\section{Profitability}

Lower profitability provides firm mangers an incentive to manipulate earnings by overstating revenues or underestimating expenses (Persons, 1995). Persons (1995) and Suyanto (2009) found that firms suffering from profitability problems are more

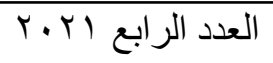

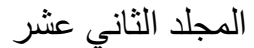


likely to have frauds in their financial reporting than other firms. In this context, Amara et al. (2013) asserted on the fact that low profitability level incites firm managers to defraud their financial results to improve overall firm performance.

This study uses (net profit/total assets) as a measurement for firm performance (profitability). Return on assets ratio- net profit/total assets- is used to indicate management efficiency in utilizing company's assets (Surjaatmja, 2018). Sign of this variable is expected to be negative. We hypothesize an inverse and statistically significant relation between firm profitability and fraudulent financial reporting. we formulate the following hypothesis:

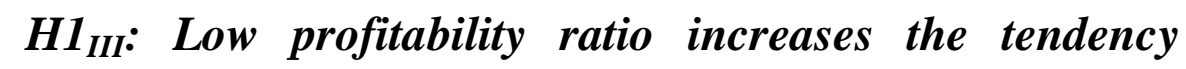
toward engaging in fraudulent financial statements

\section{Capital Turnover}

Capital turnover indicates the sales generating power of company's assets (Pearsons 1995). He argued that fraud firms are less competitive than non-fraud firms in utilizing their assets to generate sales. Capital turnover also measures the ability of management to deal with different competitive situations. The inability of management to compete successfully in the industry provide an incentive for involving in fraudulent financial reporting (Suyanto, 2009; Nakashima, 2017).

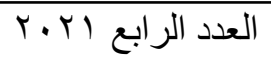


This study uses (sales/total assets) as a proxy for sales generating power of the firm. Sign of this variable is expected to be negative. We predict that capital turnover is inversely associated with the probability of fraud occurrences in financial reporting. Thus, we propose the following hypothesis:

H1 IV: Low net sales to total assets ratio increases the tendency toward engaging in fraudulent financial statements

\subsection{Proxies for Opportunity Risk Factor}

Fraud risk factors pertaining to opportunity are considered as a restraint to prevent or reduce fraud occurrence in financial reporting (Nakashima, 2017). Prior empirical research documented a significant association ineffective internal corporate governance mechanisms and fraud occurrences. Beasley (1996) found that board composition, board independence and board size had an impact on the probability of fraud occurrences in financial statement. In the same vien, Nakashima (2017) found that outside director's percentage and independence are significantly associated with the probability of fraud occurrences in financial statement.

Klein (2002) argued that corporate boards and audit committees, that are structured to work independent of management, are effective mechanisms to oversight internal 
control system and financial reporting process. When corporate governance is not robust, the internal control systems is more likely to not work well, and this internal controls weakness will fail to inhibit the opportunistic behavior of management and the occurrences of financial statements frauds. In this context, Lou and Wang (2009) stated that effectiveness of internal control system maintains financial reports' reliability and deter financial frauds while weakness of internal control system increases the probability of material misstatements in financial reports. Nakashima (2017) argued that ineffective corporate governance mechanisms are considered the constraint that working as an inhibition for fraud occurrence.

Corporate governance mechanisms that will be utilized in this study, as proxies for opportunity risk factor, include board Independence, board size, CEO duality, independence of audit committee, managerial ownership, and institutional ownership. In addition to preceding corporate governance mechanisms, we use inventory to total assets ratio.

\section{Independence of Board Members}

Beasley (1996) and Nakashima (2016) argued that higher outside directors' percentage increases the effectiveness of corporate boards in monitoring management. They documented that fraud occurrence is associated with board composition, since

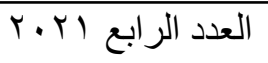

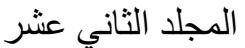


it is expected that outside directors play a pivotal role in monitoring management. In the same line, Amara et al. (2013) and Aghghaleh et al. (2014) stated that higher percentage of external directors in corporate boards decreases the probability of committing frauds. On the other side, Beasley (1996) observed that fraudulent firms have fewer outside directors on their boards compared to non-fraudulent firms.

This study uses the number of non-executives' directors to total number of directors as a proxy for board independence. Sign of this variable is expected to be negative. We predict a significantly inverse relation between board independence and the frequency of fraudulent financial reporting. Taking into consideration prior literature, we propose the following hypothesis:

H2: Independence of board of directors reduces the tendency toward engaging in fraudulent financial statements

\section{Board size}

Beasley (1996) and Nakashima (2016) argued that the size of board of directors influenced the likelihood of fraudulent financial statement. This study uses Log of number of board of directors as a proxy for board size. Sign of this variable is expected to be negative. We expect a significantly inverse

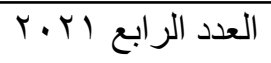

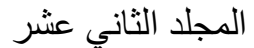


relationship between board size and fraudulent financial reporting. We formulate the following hypothesis

\section{$H 2_{I I}:$ Board size reduces the tendency toward engaging in fraudulent financial statements}

\section{CEO Duality}

SAS No.99 regarding the consideration of financial frauds in auditing financial statement asserts on the responsibility of management in designing and implementing programs to deter and detect financial statement frauds. The CEO possesses the dominant power in making decision (Skousen et al., 2009; Nakashima, 2016). They argued that the stronger the CEO's power is, the less effective internal corporate governance mechanisms are inside the firm, the higher the frequency of financial frauds occurrences in financial reports. Lou and Wang (2009) supported the separation of the board chairman position from the CEO position if a corporate board is an effective monitoring device. They argued that occupying board chairman of CEO position affects fraud occurrences.

This study uses a dummy variable with a value of 1 or 0 as a proxy for CEO Duality. Sign of this variable is expected to be positive. We expect a significantly positive association between CEO Duality and the frequency of frauds in financial reporting. We propose the following hypothesis 


\section{H2 $2_{I I I}:$ CEO Duality increases the tendency toward} engaging in fraudulent financial statements

\section{Independence of audit committee}

Audit committees are charged with oversight internal control and financial reporting process (Nakashima, 2016). Klein (2002) argued that audit committees and other corporate boards, which are formulated to work independently of management, are effective internal corporate governance mechanisms to oversight internal control and financial reporting process. Skousen et al. (2009) found the increases in independent members of audit committee, decreases the probability of frauds in financial statement. Aghghaleh et al. (2014) found a negative association between numbers of non-executives in audit committee and fraud occurrences in financial statements.

This study uses the number of non-executives in audit committee as a proxy for audit committee independence. Sign of this variable is expected to be negative. We expect an inverse relationship between the independence of audit committee and the frequency of fraudulent financial reporting. We propose the following hypothesis: 


\section{H2 $2_{I V}:$ Independence of audit committee reduces the} tendency toward engaging in fraudulent financial statements

\section{Managerial ownership}

Beasley (1996) and Skousen et al. (2009) argued that when the percentage of ownership held by executives are significant, their personal interests and financial position will be threatened by firm's financial performance. In this context, Skousen et al. (2009) documented that managerial ownership is pivotal deterrence to fraud occurrences. They observed that higher the percentage of ownership held by managers is associated with lower probability of fraud occurring.

This study uses the percentage of ownership/shares held by board of directors as a proxy for managerial ownership. Sign of this variable is expected to be negative. We predict an inverse relationship between percentage of managerial ownership and fraudulent financial reporting. We propose the following hypothesis:

$\mathrm{H}_{V}$ : Managerial ownership reduces the tendency toward engaging in fraudulent financial statements

\section{Institutional ownership}

Financial institutions have a pivotal role in oversighting and monitoring management. Nakashima (2017) argued that firms with higher percentage of ownership structure by 
financial institutions appeared not to manage earning or committing frauds in financial statements.

This study uses (Number of shares held by financial institutions / Number of shares outstanding $\times 100$ ) as a proxy for institutional ownership. Sign of this variable is expected to be negative. We expect an inverse relationship between percentage of institutional ownership and fraudulent financial reporting. We propose the following hypothesis:

H2 $2_{V I}:$ Institutional ownership reduces the tendency toward engaging in fraudulent financial statements

VII. Inventory/Total Assets.

In addition to preceding corporate governance mechanisms, we use inventory to total assets ratio since inventory is considered one of the easiest items to be manipulated (Person 1995). Kirkos et al. (2007) argued that the evaluation of inventory involves subjective estimation that create some difficulties in auditing it, hence inventory is seemed to be subject to fraudulent falsification. Inventory frauds include some tactics such as reporting it at a lower cost or recording obsolete inventories (Kirkos et al. 2007; Suyanto, 2009). Persons (1995) and Suyanto (2009) found that fraud firms have higher inventory to total assets ratio than non-fraud firms. The sign of this variable is expected to be positive. We expect positive association between inventory to total assets ratio and fraudulent financial statements. We propose the following hypothesis: 


\section{$H 2_{V I I}$ : Higher inventory to total assets ratio increases the tendency toward engaging in fraudulent financial statements}

\subsection{Proxies for Rationalization Risk Factor}

Although rationalization is considered a necessary component in the fraud triangle model, an individual's rationale or justification is very difficult to observe (Amara et al., 2013). Skousen et al. (2009) and Suyanto (2009) argued that managers' rationale or attitude is not easy to measure, which make it more difficult to find out accurate risk factors proxies for rationalization. Auditors cannot easily know what a manager's beliefs and ethical standards are. Even more, many prior empirical research (Person 1995; Kirkos et al., 2007; Aghghaleh et al., 2014) did not include risk factors proxies for rationalization in their empirical studies because of the limitation or unavailability of public data to surrogate managers' rationales or attitudes.

On the other side, Suyanto (2009) and Nakashima (2017) argued that auditors may be aware of some logical reasoning behind the possible presence of managers' attitude that induces their fraudulent behavior such as auditor changes, audit opinions, audit quality, and accruals as proxies for rationalization concerning managers' discretions. This study used total accruals and quality of external audit as proxies for rationalization risk factor. 


\section{Quality of external audit}

Farber (2005) documented that fraud firms are more likely to engage with one of Big 4 audit firms than non-fraud firms. These findings indicated that Big 4 audit-firms provide better audit quality than non-Big 4 audit-firm thus reduces firm's opportunity to involve in committing financial frauds. In the same context, Amara et al. (2013) found that Big 4 audit-firms have more ability to detect frauds in financial reporting than non-Big 4 audit-firm.

This study uses a dummy variable with a value of 1 when a firm employ big 4 firm and a value of 0 otherwise as a proxy of audit quality. The sign of this variable is expected to be positive. This study hypothesized that fraud firms, rather than non-fraud firms, are more likely to employ Big 4 audit firms. We propose the following hypothesis:

\section{H3: Auditing by Big 4 audit firm decreases the tendency} toward engaging in fraudulent financial statements

\section{Total accruals}

Skousen et al. (2009) argued that total accruals represent manager's rationales and decisions and provide insights into the rationalization behind their financial reporting. Prior literature regarding earnings management (Skousen et al., 2009; Nakashima, 2017)- that estimating firm's discretionary accruals from its total

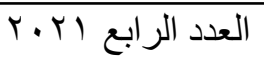

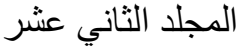


accruals- conducted that discretionary accrual is considered a metrics that provide insights into manager's discretional behavior.

This study uses (net income after tax-extraordinary incomes + extraordinary losses)-operating cash flows) as a proxy for total accruals. The sign of this variable is expected to be positive. This study hypothesized that firms manipulating earnings are more likely to rationalize their fraudulent financial reporting. We propose the following hypothesis:

$\mathrm{H3}_{\text {II: }}$ Total accruals reflect the tendency toward engaging in fraudulent financial statements

\section{DATA AND METHODOLOGY}

\subsection{Sample Selection and data sources}

The sample utilized to examine the study hypotheses represents 110 of publicly traded Egyptian firms from year 2011 to 2017 with total observations of 759 (after excluding the 11 missing observations): 201 of which are fraudulent observations and 558 non-fraudulent observations. Table no. (1) presents the sectorial distribution of study's sample. Appendix no. (1) presents the full list of companies included in the study's sample.

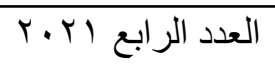

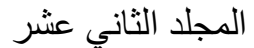


Can Fraud Triangle Model Predict Fraudulent Financial Statements?

Dr/Shaimaa Fikry Mehanna \& Dr/Mohammed Mahmoud Soliman

Table (1)

The sectorial distribution of study's sample

\begin{tabular}{|c|c|c|}
\hline Sector & No. & $\%$ \\
\hline Chemicals & 7 & 7.47 \\
\hline Basic Resources & 8 & $\begin{array}{l}. T V \\
\end{array}$ \\
\hline Industrial Goods and Services and Automobiles & 12 & $1 \cdot .9$ \\
\hline Health Care and Pharmaceuticals & 7 & 7.47 \\
\hline Personal and Household Products & 9 & $\Lambda .1 \wedge$ \\
\hline Constructions and Materials & 21 & 19 \\
\hline Real Estate & 17 & $10 .\{$ \\
\hline Travel and Leisure & 9 & $\Lambda .11$ \\
\hline Total & 110 & 1 \\
\hline
\end{tabular}

This study utilized data from two sources; Egyptian for information dissemination company and Mubasher Misr Database to get the published annual report of the publicly traded companies needed to collect corporate governance mechanisms data and calculate the necessary financial statement ratios. We eliminated financial institutions (insurance companies and banks) and any missing or incomplete data. We excluded financial institutions from the sample because their specialized nature as they are lacking certain financial information such as inventories.

\subsection{Model Specification}

This study investigates whether the three risk components of the fraud triangle model (Pressure, Opportunity, Rationalization) can be applied to fraudulent financial statements as following:

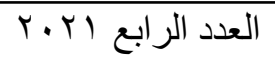$$
\text { المجلد الثاني عشر }
$$ 


$$
\text { FRAUD }_{t}=f\left(\text { Pressure }_{t}, \text { Opportunity }_{t}, \text { Rationalization }_{t}\right)
$$

Where:

Pressure represents to what extent the manager in authority has a motivation to involve in committing financial frauds. Opportunity represents to what extent financial frauds could be committed due to weak corporate governance mechanisms or ineffective internal control systems. Rationalization represents to what extent the attitudes or ethical values of manager in authority would allow him to engage in financial frauds (Nakashima, 2017). Therefore, Nakashima (2017) argued that it is expected that if pressure, opportunity, rationalization equal 0 , then it is expected that fraud will be equal 0 . On contrary, if all the three risk components coexist in given situation, the probability of fraudulent financial statements occurrence would be very high.

\subsection{The Empirical Model:}

Since the dependent variable, Fraud, is a dummy variable, the study uses the logistic regression to examine the relationship between fraud risk factors of fraud triangle model and fraudulent financial statements. The empirical model includes risk factors related to pressure, opportunity and rationalization that lead to the probability of committing frauds in the financial statements.

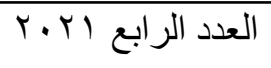

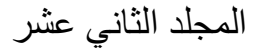


The following logistic regression model is utilized to test the study's hypotheses:
FRAUDi $=\beta 0+\beta 1$ LEV $_{i}+\beta 2$ LIQ $_{i}+\beta 3$ PROFT $_{i}+$ $\beta 4$ SALTA $_{i}+\beta 5$ BIND $_{i}+\beta 6$ BSIZE $_{i}+\beta 7$ DUAL $_{i}+\beta 8$ AUDIND $_{i}+\beta$ MGOWN $_{i}+\beta 10$ ISOWN $_{i}+\beta 11$ INVTA $_{i}+\beta 12$ BIG $_{i}+\beta 13$ TAC $_{i}+\beta 14$ SIZE $_{i}+\varepsilon_{i}$

\section{Dependent Variable:}

FRAUD, the dependent variable, is a dummy variable with value of (1) if the firm is engaged in committing financial statement frauds and value of (0) otherwise. We define fraudulent firms using Beneish model. Beneish model, since its introduction in 1999 till now, is widely used by researchers and academics (Beneish, 1999).

Beneish model is considered the most comprehensive model to measure earnings' manipulation. Beneish (1999), Surjaatmaja (2018), and Fitri (2019) argued that many models for detecting earnings' manipulation are better to be applied in highly developed or complex economies, however, in emerging economies, Beneish model is proven to be reliably applicable.

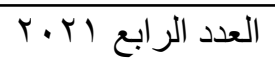

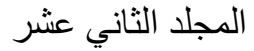


Beneish model equation:

$$
\begin{array}{r}
M=-4,840+0,920 D S R I+0,528 G M I+0,0404 A Q I+ \\
0,892 S G I+0,115 D E P I-0,172 S G A I+4,679 T A T A-0,327 L V G I
\end{array}
$$

Where:

- M represents the M-score of Beneish model equation. It has a value greater than -2.22 for fraud firms.

- DSRI represents Days' Sales in Receivables Index (ratio of days' sales in receivables VS. prior year).

- GMI represents Gross Margin Index (ratio of gross margin prior year VS. current year).

- AQI represents Asset Quality Index (ratio of non-current assets other than plant, property, and equipment to total assets VS. prior year).

- SGI represents Sales Growth Index (ratio of sales VS. prior year).

- DEPI represents Depreciation Index (ratio of the rate of depreciation current year VS. prior year).

- SGAI represents Sales, General and Administrative expenses Index (ratio of SGA expenses VS. prior year).

- LVGI represents Leverage Index (ratio of total debt to total assets VS. prior year).

- TATA represents Total Accruals to Total Assets (the change in working capital accounts other than cash less depreciation).

Fraudulent firms have value of M-score greater than -2.22. Fraudulent firms are given "1", while non-fraudulent firms are

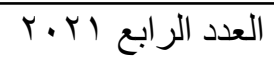
المجلد الثاني عثر 
Can Fraud Triangle Model Predict Fraudulent Financial Statements?

Dr/Shaimaa Fikry Mehanna \& Dr/Mohammed Mahmoud Soliman

given "0" (Beneish, 1999; Surjaatmaja, 2018; Fitri, 2019). After, applying this equation, we found that 201 observations are assumed to be fraudulent, while 558 observations are assumed to be non-fraudulent. This means around $26 \%$ of the sample are seems to manipulate their financial statements.

Beneish model has two versions; the first version uses the preceding eight ratios, while the second version of Beneish model depends only on five ratios. Surjaatmaja (2018) argued that depending only on five ratios give significant results for the model. The M-score equation of the second version of Beneish model:

$$
M=-6,065+0,823 D S R I+0,906 G M I+0,593 A Q I+0,
$$

$717 S G I+0,107 D E P$

The current study uses the first version of Beneish model. The following table no. (2) represents the Beneish model variables and its measurement according to Beneish (1999).

Table (2)

Beneish model variables (Beneish, 1999)

\begin{tabular}{|c|c|c|}
\hline Title & Variables & Measurement \\
\hline $\begin{array}{l}\text { Days Sales in } \\
\text { Receivables } \\
\text { Index (DSRI) }\end{array}$ & $\begin{array}{l}\text { Ratio of days sales in } \\
\text { receivable in } \mathrm{Yr}_{\cdot t} \text { VS. days } \\
\text { sales in receivable in } \mathrm{Yr}_{t-1}\end{array}$ & $\begin{array}{l}\left(\text { Receivables }_{t} / \text { SSales }_{t}\right) /(\text { Receivables } \\
\left.{ }_{t-1} / \text { Sales }_{t-1}\right)\end{array}$ \\
\hline $\begin{array}{l}\text { Gross Margin } \\
\text { Index }(G M I):\end{array}$ & $\begin{array}{l}\text { Ratio of gross margin in } Y r_{\cdot t-1} \\
\text { VS. gross margin in } Y r_{\cdot t}\end{array}$ & $\begin{array}{l}\left(\text { Sales }_{t-1} \text {-Costs of Goods Sold } t_{t-l} / \text { Sales }\right. \\
t-1) / \\
\left(\text { Sales }_{t}-\text { Costs of Goods Sold }{ }_{t} \text { Sales }_{t}\right)\end{array}$ \\
\hline $\begin{array}{l}\text { Asset Quality } \\
\text { Index }(A Q I)\end{array}$ & $\begin{array}{l}\text { Ratio of non-current assets } \\
\text { other than property plant and } \\
\text { equipment (PPE) total assets } \\
\text { in Yr.t } V S . Y r_{\cdot t-1}\end{array}$ & $\begin{array}{l}1-\left(\text { Current Assets }_{t}+P P E_{t} / \text { Total }\right. \\
\left.\text { Assets }_{t}\right) / \\
1-\left(\text { Current Assets }_{t-1}+P P E_{t-1} / \text { Total }\right. \\
\left.\text { Assets }_{t-1}\right)\end{array}$ \\
\hline
\end{tabular}

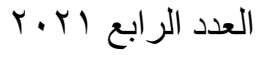

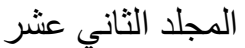


Can Fraud Triangle Model Predict Fraudulent Financial Statements?

Dr/Shaimaa Fikry Mehanna \& Dr/Mohammed Mahmoud Soliman

\begin{tabular}{|c|c|c|}
\hline Title & Variables & Measurement \\
\hline $\begin{array}{l}\text { Sales Growth } \\
\text { Index (SGI) }\end{array}$ & $\begin{array}{l}\text { Ratio of sales in } \mathrm{Yr}_{\cdot t} \text { VS. sales } \\
\text { in } Y r_{\cdot t-1}\end{array}$ & $\left(\right.$ Sales $\left._{t}\right) /\left(\right.$ Sales $\left._{t-1}\right)$ \\
\hline $\begin{array}{l}\text { Depreciation } \\
\text { Index (DEPI) }\end{array}$ & $\begin{array}{l}\text { Ratio of rate of depreciation } \\
\text { in } Y r_{\cdot t-1} \quad V S . \quad \text { rate of } \\
\text { depreciation in } Y r_{\cdot t} .\end{array}$ & $\begin{array}{l}\text { (Depreciation }{ }_{t-1} / \text { Depreciation }_{t-1} \\
\left.+P P E_{t-1}\right) / \\
\left(\text { Depreciation }_{t} / \text { Depreciation }\right. \\
\left.+P P E_{t}\right)\end{array}$ \\
\hline $\begin{array}{l}\text { Sales General } \\
\text { and Administ- } \\
\text { rative Expenses } \\
\text { Index }(S G A I)\end{array}$ & $\begin{array}{l}\text { Ratio of SGA Expense to sales } \\
\text { in Yr.t VS. SGA Expense to } \\
\text { sales in Yr.t-l. }\end{array}$ & $\begin{array}{l}\left(\text { SGA Expense }_{t} / \text { Sales }_{t}\right) / \\
\left(\text { SGA Expense }_{t-1} / \text { Sales }_{t-1}\right)\end{array}$ \\
\hline $\begin{array}{l}\text { Leverage Index } \\
(L V G I)\end{array}$ & $\begin{array}{l}\text { Ratio of total debt to total } \\
\text { assets in } Y r_{\cdot} \text { VS. total debt to } \\
\text { total assets in } Y r_{\cdot t-1} .\end{array}$ & 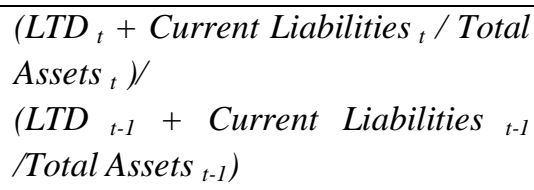 \\
\hline $\begin{array}{l}\text { Total Accruals } \\
\text { to Total Assets } \\
\text { (TATA) }\end{array}$ & $\begin{array}{l}\text { The change in working } \\
\text { capital accounts other than } \\
\text { cash less depreciation. }\end{array}$ & $\begin{array}{l}\text { Income from continuing operations }{ }_{t} \\
\text {-cash flow from operations } t_{t} \text { total } \\
\text { assets }_{t}\end{array}$ \\
\hline
\end{tabular}

\section{Independent Variables:}

\section{(Fraud risk factors of fraud triangle model)}

\section{a. Proxies for Pressure Risk Factor}

The current study hypothesize that the risk factors related to pressure are significantly associated with the frequency of fraud occurrences in financial statements. More specifically, this study hypothesizes that financial leverage, liquidity, net profitability, and capital turnover are associated with fraudulent

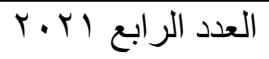

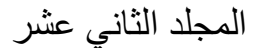


financial statements. Hence, the pressure component of fraud triangle model includes the following variables:

- Financial Leverage (LEV): Total Liability/Total Assets

- Liquidity (LIQ): Current Assets/Current Liabilities

- Profitability (PROFT): Net Profit/Total Assets

- Capital Turnover (SALTA): Net Sales/Total Assets

\section{b. Proxies for Opportunity Risk Factor}

We hypothesize 2 that risk factors related to opportunity are significantly associated with the probability of fraud occurrences in financial statements. Specifically, this study hypothesizes that independence of board members, board size, CEO duality, independence of audit committee, managerial ownership, institutional ownership, and inventory to total assets ratio are associated with the frequency of engagement in financial statement frauds. Hence, the opportunity component of fraud triangle model includes the following variables:

- Independence of Board Members (BIND): Non-executives' directors to the total number of directors

- Board size (BSIZE): Log of number of board of directors

- CEO Duality (DUAL): Dummy variable with a value of 1 or 0

- Independence of audit committee (AUDIND): number of non-executives in audit committee 
- Managerial ownership (MGOWN): percentage of ownership held by board of directors

- Institutional ownership (ISOWN): Number of shares held by financial institutions / Number of shares outstanding $\times 100$

- Inventory/Total Assets (INVTA): Total inventory/total assets

\section{c. Proxies for rationalization Risk Factor}

We hypothesize that risk factors related to rationalization are significantly associated with the increasing tendency toward engaging in financial statements frauds. This study hypothesizes that the quality of the external audit and total accruals are associated with the tendency toward engaging in committing financial statement frauds. Hence, the rationalization component of fraud triangle model includes the following variables:

- Quality of the external audit (BIG4): dummy variable with a value of (1) when a firm engages with big 4 auditors and a value of (0) otherwise

- Total accruals TA: (net income after tax-extraordinary incomes + extraordinary losses)-operating cash flows

\section{Control Variable:}

Based on prior literature (Pearsons, 1995; Suyanto, 2009; Lou and Wang, 2009, Amara et al., 2013; Nakashima, 2017), this study uses firm size as a control variable. They provided evidence supported that small firms, rather than big firms, have 
Can Fraud Triangle Model Predict Fraudulent Financial Statements?

Dr/Shaimaa Fikry Mehanna \& Dr/Mohammed Mahmoud Soliman

higher tendency toward engaging in financial statements frauds, since large firms seems having stronger internal control system than small firms. This study uses logarithm of a firm's total assets to measure firm size. The sign of this variable is expected to be negative. This study expects an inverse relationship between firm size and financial frauds

The following table no. (3) summarizes the measurement of the independent variables pertaining to the three components of fraud triangle model and displays the previous work related to each risk factor.

Table (3)

Measures of the independent variables

\begin{tabular}{|c|c|c|c|}
\hline Risk Factor & Proxies/Variables & Measurement & Previous work \\
\hline \multirow[t]{4}{*}{ Pressure } & $\begin{array}{l}\text { Financial Leverage } \\
(\mathrm{LEV})\end{array}$ & $\begin{array}{ll}\text { Total } & \text { Liability/Total } \\
\text { Assets } & \end{array}$ & \begin{tabular}{|ll}
- & Pearsons (1995) \\
- & Skousen et al. (2008) \\
- & Suyanto (2009) \\
- & Lou and Wang (2009) \\
- & Amara et al. (2013) \\
- & Nakashima (2017)
\end{tabular} \\
\hline & Liquidity (LIQ) & $\begin{array}{l}\text { Current Assets/Current } \\
\text { Liabilities }\end{array}$ & \begin{tabular}{|ll}
- & Kirkos et al. (2007) \\
- & Amara et al. (2013) \\
- & Fitri et al. (2019)
\end{tabular} \\
\hline & $\begin{array}{l}\text { Profitability } \\
\text { (PROFT) }\end{array}$ & Net Profit/Total Assets & $\begin{array}{ll}- & \text { Pearsons (1995) } \\
- & \text { Suyanto (2009) } \\
- & \text { Amara et al. (2013) } \\
- & \text { Nakashima (2017) }\end{array}$ \\
\hline & $\begin{array}{ll}\text { Capital } & \text { Turnover } \\
\text { (SALTA) } & \end{array}$ & Sales/Total Assets & $\begin{array}{ll}- & \text { Pearsons (1995) } \\
- & \text { Suyanto (2009) }\end{array}$ \\
\hline Opportunity & $\begin{array}{l}\text { Independence of } \\
\text { Board } \quad \text { Members }\end{array}$ & $\begin{array}{l}\text { Non-executives' directors } \\
\text { to total number of }\end{array}$ & \begin{tabular}{|ll}
- & Beasley (1996) \\
- & Skousen et al. (2008)
\end{tabular} \\
\hline
\end{tabular}

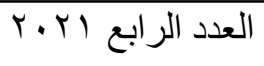

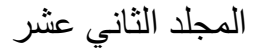


Can Fraud Triangle Model Predict Fraudulent Financial Statements?

Dr/Shaimaa Fikry Mehanna \& Dr/Mohammed Mahmoud Soliman

\begin{tabular}{|c|c|c|c|}
\hline Risk Factor & Proxies/Variables & Measurement & Previous work \\
\hline & (BIND) & directors & $\begin{array}{ll}- & \text { Amara et al. (2013) } \\
- & \text { Aghghaleh et al. (2014) } \\
- & \text { Nakashima (2017) }\end{array}$ \\
\hline & Board size (BSIZE) & $\begin{array}{l}\text { Log of number of board } \\
\text { of directors }\end{array}$ & $\begin{array}{ll}- & \text { Beasley (1996) } \\
- & \text { Nakashima (2017) }\end{array}$ \\
\hline & $\begin{array}{ll}\text { CEO } & \text { Duality } \\
\text { (DUAL) } & \end{array}$ & $\begin{array}{l}\text { Dummy variable with a } \\
\text { value of } 1 \text { or } 0\end{array}$ & $\begin{array}{ll}- & \text { Lou and Wang (2009) } \\
- & \text { Nakashima (2017) }\end{array}$ \\
\hline & $\begin{array}{l}\text { Independence of } \\
\text { audit committee } \\
(\text { AUDIND) }\end{array}$ & $\begin{array}{l}\text { number of non-executives } \\
\text { in audit committee }\end{array}$ & $\begin{array}{ll}- & \text { Beasley et al. (2000) } \\
- & \text { Skousen et al. (2008) } \\
- & \text { Aghghaleh et al. (2014) } \\
- & \text { Nakashima (2017) }\end{array}$ \\
\hline & $\begin{array}{l}\text { Managerial } \\
\text { ownership } \\
(\text { MGOWN) }\end{array}$ & $\begin{array}{l}\text { Percentage of ownership } \\
\text { held by board of directors }\end{array}$ & $\begin{array}{ll}- & \text { Beasley (1996) } \\
- & \text { Skousen et al. (2008) } \\
- & \text { Nakashima (2017) }\end{array}$ \\
\hline & $\begin{array}{l}\text { Institutional } \\
\text { ownership (ISOWN) }\end{array}$ & $\begin{array}{l}\text { Number of shares held by } \\
\text { financial institutions } / \\
\text { Number of shares } \\
\text { outstanding } \times 100\end{array}$ & $\begin{array}{ll}- & \text { Skousen et al. (2008) } \\
\text { - } & \text { Nakashima (2017) }\end{array}$ \\
\hline & $\begin{array}{l}\text { Inventory to Total } \\
\text { Assets (INVTA) }\end{array}$ & $\begin{array}{ll}\text { Total } & \text { inventory/total } \\
\text { assets } & \\
\end{array}$ & $\begin{array}{ll}- & \text { Pearsons (1995) } \\
- & \text { Kirkos et al. (2007) } \\
- & \text { Suyanto (2009) }\end{array}$ \\
\hline \multirow[t]{2}{*}{ Rationalization } & $\begin{array}{l}\text { The quality of the } \\
\text { external } \\
\text { (BIG4) }\end{array}$ & $\begin{array}{l}\text { dummy variable with a } \\
\text { value of (1) when a firm } \\
\text { engages with big } 4 \text { auditors } \\
\text { and (0) otherwise }\end{array}$ & $\begin{array}{ll}- & \text { Suyanto (2009) } \\
- & \text { Amara et al. (2013) }\end{array}$ \\
\hline & Total accruals TA & \begin{tabular}{l} 
(Net income after tax- \\
extraordinary incomes + \\
extraordinary \\
\multicolumn{2}{c}{ losses)- } \\
operating cash flows
\end{tabular} & $\begin{array}{ll}- & \text { Skousen et al. (2008) } \\
- & \text { Nakashima (2017) }\end{array}$ \\
\hline
\end{tabular}

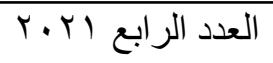




\section{RESULTS AND DISCUSSION}

\subsection{Descriptive Statistics and Correlation Analysis}

Table no. (4) shows the descriptive statistics for fraudulent firms and non-fraudulent firms and the results of paired t-test. Descriptive statistics gives us a general idea about the characteristics of the study variables. There is positive significant difference in fraud risk factors such as firm profitability (PROFT), independence of board of directors (BIND), and total accruals (TA) between fraudulent firms and non-fraudulent firms.

We found that fraudulent firms have a higher profitability ratio than non-fraudulent firms, which is inconsistent with prior literature (Pearsons, 1995; Suyanto, 2009; Amara et al., 2013) that suggested that firms suffering from profitability problems are more likely to have financial frauds than other firms and mangers of such firms have an incentive to engage in financial frauds to portray a good picture of firm performance.

There are significant differences in the opportunity factor; board independence (BIND) between fraud firms and non-fraud firms. Fraudulent firms have a higher non-executive' directors in their boards than non-fraudulent firms, which is inconsistent with prior literature (Beasley,1996; Skousen et al., 2008; Amara et al., 2013; Aghghaleh et al., 2014) that suggested that outside 
Can Fraud Triangle Model Predict Fraudulent Financial Statements?

Dr/Shaimaa Fikry Mehanna \& Dr/Mohammed Mahmoud Soliman

directors play a pivotal role in monitoring management and stated that higher percentage of non-executive' directors in corporate boards decreases the probability of committing frauds.

In addition, total accruals as rationalization risk factor differ significantly between fraudulent and non-fraudulent firms. We found that the fraud firms have greater accruals than non-fraud firms. This is consistent with Skousen et al. (2008) and Nakashima (2017) that stated that the quality of earnings in fraudulent firms is lower than the quality of earnings in non-fraudulent firms.

Table (4)

Descriptive Statistics

\begin{tabular}{|c|c|c|c|c|c|c|c|}
\hline \multirow[b]{2}{*}{$\begin{array}{l}\text { Risk } \\
\text { Factor }\end{array}$} & \multirow[b]{2}{*}{ Variable } & \multicolumn{2}{|c|}{ FRAUD FIRMS } & \multicolumn{2}{|c|}{ NON- FRAUD FIRMS } & \multirow[b]{2}{*}{$\begin{array}{c}\mathrm{t}- \\
\text { value }\end{array}$} & \multirow[b]{2}{*}{$\begin{array}{c}\text { Significanc } \\
\text { e }\end{array}$} \\
\hline & & Mean & $\begin{array}{c}\text { Std. } \\
\text { Deviation }\end{array}$ & Mean & $\begin{array}{c}\text { Std. } \\
\text { Deviation }\end{array}$ & & \\
\hline \multirow[t]{4}{*}{ Pressure } & LEV & 0.4310 & 0.2560 & 0.4241 & 0.2808 & 0.303 & 0.762 \\
\hline & LIQ & 3.0901 & 4.9335 & 3.6031 & 8.5095 & -0.807 & 0.420 \\
\hline & PROFT & 0.0815 & 0.0968 & 0.04852 & 0.0995 & 4.065 & 0.000 \\
\hline & SALTA & 0.6912 & 0.7475 & 0.71853 & 0.7272 & -0.453 & 0.651 \\
\hline \multirow[t]{6}{*}{ Opportunity } & BIND & 0.6779 & 0.2275 & 0.6410 & 0.2489 & 1.923 & 0.055 \\
\hline & BSIZE & 0.8734 & 0.1579 & 0.8591 & 0.1536 & 1.124 & 0.261 \\
\hline & AUDIND & 0.8696 & 0.2435 & 0.8981 & 0.2047 & -1.481 & 0.140 \\
\hline & MGOWN & 0.0884 & 0.1757 & 0.0745 & 0.1646 & 1.005 & 0.315 \\
\hline & ISOWN & 0.5484 & 0.3303 & 0.5670 & 0.3106 & -0.712 & 0.477 \\
\hline & INVTA & 0.1766 & 0.1429 & 0.1752 & 0.1401 & 0.113 & 0.910 \\
\hline Rationalization & TA & 0.0234 & 0.1369 & -0.0056 & 0.0957 & 2.777 & 0.006 \\
\hline Control Variable & FSIZE & 8.6779 & 0.5729 & 8.7190 & 0.5715 & -0.875 & 0.382 \\
\hline
\end{tabular}

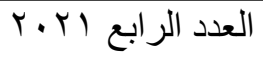

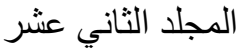


Following the descriptive analysis of the study variables, Table no. (5) presents Pearson's correlation matrix. The correlation matrix shows that whether the correlations' degree between independent variables are either low or moderate; the highest correlation coefficient in the study sample exists between managerial ownership (MGOWN) and institutional ownership (ISOWN), with a coefficient of 0.583 , suggesting that there is an absence of multicollinearity problem between the independent variables. Pearson's coefficient between each pair of independent variables should not exceed 80\%; otherwise, any two independent variables with a coefficient more than $80 \%$ may be suspected of exhibiting multicollinearity problem (Abdelsalam et al., 2008).

Correlation analysis is performed to investigate whether financial frauds are correlated to risk factors of fraud triangle model. Table no. (4) represents the correlation coefficient between financial fraud and financial ratios representing firm characteristics and other internal mechanisms representing a firm's corporate governance status.

Regarding the correlation coefficient of financial statements fraud and financial ratios representing the pressure dimension of fraud triangle model, the Pearson correlation matrix shows that financial fraud (FRAUD) has insignificant correlations with firm financial leverage (LEV) and firm liquidity (LIQ), which are opposite to what was expected in prior literature

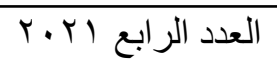

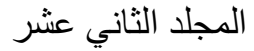


(Pearsons, 1995; Suyanto, 2009; Amara et al., 2013) that suggested that firms with high leverage and liquidity problems are more likely to engage in frauds. On the other hand, the Pearson correlation between financial statements fraud and firm profitability (PROFT) is (0.146) which is statistically significant and consistent with prior literature.

Regarding the correlation coefficient of financial statements fraud and corporate governance attributes, the Pearson correlation between fraud (FRAUD) and duality (DAUL) is (0.086) which is statistically significant and consistent to what was suggested in Lou and Wang (2009) and Nakashima (2017), while fraud (FRAUD) is insignificant with other attributes of corporate governance.

Regarding the correlation coefficients of fraud and risk factors representing the rationalization component of fraud tringle model, the Pearson correlation coefficient between fraud (FRAUD) and big 4 (BIG4) is (0.087), which is statistically significant but in the opposite direction to what was expected in prior literature (Suyanto, 2009; Amara et al.,2013). However, the Pearson correlation coefficient between fraud (FRAUD) and total accruals (TA) are (0.118), which is statistically significant and consistent to what was suggested in prior literature (Skousen et al., 2008; Nakashima, 2017). This suggests that fraudulent financial statement is correlated with risk factors representing rationalization such as total accruals positively.

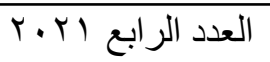


Can Fraud Triangle Model Predict Fraudulent Financial Statements?

Dr/Shaimaa Fikry Mehanna \& Dr/Mohammed Mahmoud Soliman

Table (5)

Person Correlation matrix

\begin{tabular}{|c|c|c|c|c|c|c|c|c|c|c|c|c|c|c|c|}
\hline & Frad & LEV & L10 & pror & SALTA & BIVD & Bsize & DFAM & $\begin{array}{c}\text { ALDIN } \\
\text { D }\end{array}$ & $\begin{array}{c}\text { scow } \\
\mathrm{x}\end{array}$ & Isowx & INTA & BICA & $\mathrm{TA}$ & $\begin{array}{l}\mathrm{FSI} \\
\mathrm{ZIE} \\
\end{array}$ \\
\hline Frned & 1 & & & & & & & & & & & & & & \\
\hline LIV & $\begin{array}{l}.011 \\
.762 \\
\end{array}$ & 1 & & & & & & & & & & & & & \\
\hline LI0 & $\begin{array}{l}.029 \\
.420 \\
\end{array}$ & $\begin{array}{l}.325^{\circ} \\
.000 \\
\end{array}$ & 1 & & & & & & & & & & & & \\
\hline pror & $\begin{array}{l}.146^{\circ} \\
.000 \\
\end{array}$ & $\begin{array}{l}.443^{*} \\
.000 \\
\end{array}$ & $\begin{array}{l}.011 \\
.760 \\
\end{array}$ & 1 & & & & & & & & & & & \\
\hline$\underset{A}{\text { SALT }}$ & $\begin{array}{l}.016 \\
.651 \\
\end{array}$ & $\begin{array}{l}.120^{*} \\
.000\end{array}$ & $\begin{array}{l}.110^{*} \\
.002 \\
\end{array}$ & $\begin{array}{c}.19704 \\
.000 \\
\end{array}$ & 1 & & & & & & & & & & \\
\hline BIND & $\begin{array}{l}.067 \\
.066 \\
\end{array}$ & $\begin{array}{l}.173^{*} \\
.000\end{array}$ & $\begin{array}{l}.072^{\circ} \\
.043^{\circ} \\
\end{array}$ & $\begin{array}{r}.034 \\
352 \\
\end{array}$ & $\begin{array}{l}.204 * * \\
.000 \\
\end{array}$ & 1 & & & & & & & & & \\
\hline$\underset{\mathrm{E}}{\mathrm{BS1Z}}$ & $\begin{array}{l}.041 \\
261 \\
\end{array}$ & $\begin{array}{l}.188^{*} \\
.000\end{array}$ & $\begin{array}{l}.018 \\
.616 \\
\end{array}$ & $\begin{array}{c}243 * * \\
.000\end{array}$ & $\begin{array}{l}.002 \\
957 \\
\end{array}$ & $\begin{array}{l}.473^{*} \\
.000\end{array}$ & 1 & & & & & & & & \\
\hline $\mathrm{DtA}_{\mathrm{I}}$ & $\begin{array}{l}.036 \\
.018 \\
\end{array}$ & $\begin{array}{l}.033^{\circ} \\
.023\end{array}$ & $\begin{array}{l}.035 \\
.390 \\
\end{array}$ & $\begin{array}{l}.011 \\
.770\end{array}$ & $\begin{array}{c}.126 * * \\
.000\end{array}$ & $\begin{array}{l}.217^{\circ} \\
.000\end{array}$ & $\begin{array}{l}.058 \\
.113 \\
\end{array}$ & 1 & & & & & & & \\
\hline$\underset{\text { ND }}{\text { AtDI }}$ & $\begin{array}{r}.058 \\
.100 \\
\end{array}$ & $\begin{array}{l}.257^{\circ} \\
.000 \\
\end{array}$ & $\begin{array}{l}.072^{\circ} \\
.046 \\
\end{array}$ & $\begin{array}{c}.104 * * \\
.004 \\
\end{array}$ & $\begin{array}{l}.353 * * \\
.000 \\
\end{array}$ & $\begin{array}{l}.461^{*} \\
.000 \\
\end{array}$ & $\begin{array}{l}.145^{*} \\
.000 \\
\end{array}$ & $\begin{array}{c}-196 * * \\
.000 \\
\end{array}$ & 1 & & & & & & \\
\hline $\begin{array}{l}\text { sco } \\
\text { wX }\end{array}$ & $\begin{array}{l}.036 \\
.315\end{array}$ & $\begin{array}{l}.154^{*} \\
.000\end{array}$ & $\begin{array}{l}.051 \\
.161 \\
\end{array}$ & $\begin{array}{l}.066 \\
.068 \\
\end{array}$ & $\begin{array}{l}.035 \\
.939 \\
\end{array}$ & $\begin{array}{l}.040 \\
.275 \\
\end{array}$ & $\begin{array}{l}.022 \\
552 \\
\end{array}$ & $\begin{array}{l}.016 \\
.651 \\
\end{array}$ & $\begin{array}{l}.006 \\
.864 \\
\end{array}$ & 1 & & & & & \\
\hline 15ow & $\begin{array}{l}.026 \\
.477 \\
\end{array}$ & $\begin{array}{l}.265^{\circ} \\
.000 \\
\end{array}$ & $\begin{array}{l}.220^{*} \\
.000 \\
\end{array}$ & $\begin{array}{l}.046 \\
.206 \\
\end{array}$ & $\begin{array}{c}.127 * 0 \\
.000\end{array}$ & $\begin{array}{l}.166^{\circ} \\
.000 \\
\end{array}$ & $\begin{array}{l}.046 \\
.207 \\
\end{array}$ & $\begin{array}{l}.013 \\
.721 \\
\end{array}$ & $\begin{array}{l}.077 \\
.035 \\
\end{array}$ & $\begin{array}{l}.533^{*} \\
.000 \\
\end{array}$ & 1 & & & & \\
\hline$\underset{A}{\mathrm{NVTT}}$ & $\begin{array}{l}.004 \\
910\end{array}$ & $\begin{array}{l}.155 " \\
.000\end{array}$ & $\begin{array}{l}.039 \\
.285\end{array}$ & $\begin{array}{c}.095 * * \\
.009\end{array}$ & $\begin{array}{c}.099 * * \\
.006\end{array}$ & $\begin{array}{l}.078^{\circ} \\
.031\end{array}$ & $\begin{array}{l}.194^{*} \\
.000\end{array}$ & $\begin{array}{l}.145^{*} \\
.000\end{array}$ & $\begin{array}{l}.070 \\
.055\end{array}$ & $\begin{array}{l}.110^{*} \\
.001\end{array}$ & $\begin{array}{l}.005 \\
.01\end{array}$ & 1 & & & \\
\hline BICA & $\begin{array}{l}.087 \\
.017\end{array}$ & $\begin{array}{l}.050 \\
.172\end{array}$ & $\begin{array}{l}.150^{-*} \\
.000\end{array}$ & $\begin{array}{l}.056 \\
.126\end{array}$ & $\begin{array}{l}.043 \\
.296\end{array}$ & $\begin{array}{c}.02 \% \\
.000\end{array}$ & $\begin{array}{l}.1966^{*} \\
.000\end{array}$ & $\begin{array}{l}.294^{*} \\
.000\end{array}$ & $\begin{array}{l}.220^{-*} \\
.000\end{array}$ & $\begin{array}{l}.124^{-} \\
.001\end{array}$ & $\begin{array}{l}.167 * * \\
.000\end{array}$ & $\begin{array}{l}.030 \\
.411\end{array}$ & 1 & & \\
\hline IA & $.118^{*}$ & $-163^{*}$ & $.104^{*}$ & $262 \%$ & .063 & .056 & .096 & .003 & $.124^{-*}$ & $.073^{\circ}$ & $-163{ }^{* *}$ & . 1666 & .042 & 1 & \\
\hline
\end{tabular}

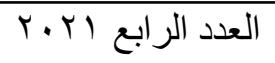




\subsection{Regression Analyses}

To generalize the logistic regression model, the following underlying cross-validating assumptions (i.e., auto-correlation, normality for distributed errors and multi-collinearity) are checked to assure that they have been met. Table (6) presents the regression results examining the potential effects of the fraud risk factors for Pressure and the probability of fraudulent financial statements.

Table no. (6) presents the logistic regression results examining the potential effects of risk factors representing the pressure dimension of the fraud triangle model on the engagement in financial fraud. In model (1), Pseudo R2 is (0.048) which is relatively low and the p-value for model (1) is significant at (0.000). Firm financial leverage (LEV), capital turnover (SALTA), and firm size (FSIZE) are significantly associated in the predicted sign with financial statements frauds (FRAUD). These results indicate that smaller firms rather than big size firms with higher leverage LEV and lower sales to total assets (SALTA) have higher tendency toward engaging in fraudulent financial statements and tries to make their financial reports look better through cooking their books. These findings are in line with Pearsons (1995), Lou and Wang (2009), Aghghaleh et al. (2014), and Nakashima (2017).

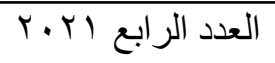


Can Fraud Triangle Model Predict Fraudulent Financial Statements?

Dr/Shaimaa Fikry Mehanna \& Dr/Mohammed Mahmoud Soliman

Firm profitability (PROFT) is significantly associated with financial statements frauds, however, in the opposite direction to what was expected in prior literature. This result indicates that firms with higher profitability (PROFT) are more likely to engage in financial frauds rather than firms with lower profitability ratio. This finding contradicts with Pearsons (1995), Suyanto (2009), and Amara et al. (2013). Liquidity (LIQ) is statistically insignificant with financial statements frauds. This finding is in line with Amara et al. (2013) and Fitri et al. (2019) that documented an insignificant association between firm liquidity (LIQ) and financial frauds (FRAUD).

\section{Table (6)}

Logistic regression results for model (1) pressure variables

\begin{tabular}{|c|c|c|c|c|c|c|}
\hline \multicolumn{7}{|c|}{ FRAUDi $=\beta 0+\beta 1$ LEVi $+\beta 2$ LIQ $\mathrm{i}+\beta 3$ PROFT $\mathrm{i}+\beta 4$ SALTA $\mathrm{i}+\varepsilon \mathrm{i}$} \\
\hline $\begin{array}{l}\text { Independent } \\
\text { variable }\end{array}$ & $\begin{array}{l}\text { Expected } \\
\text { sign }\end{array}$ & Coef. & Std. Err. & $\mathrm{Z}$ & $\mathrm{P}>|\mathrm{z}|$ & VIF \\
\hline LEV & + & 1.023274 & 0.3813002 & 2.68 & $0.007 * *$ & 1.53 \\
\hline LIQ & - & -0.0120043 & 0.0121324 & -0.99 & 0.322 & 1.24 \\
\hline PROF & - & 5.473596 & 0.9994832 & 5.48 & $0.000 * * *$ & 1.44 \\
\hline SALTA & - & -0.315169 & 0.1482603 & -2.13 & $0.034 * *$ & 1.16 \\
\hline FSIZE & - & -0.4150878 & 0.1656912 & -2.51 & $0.012 * *$ & 1.17 \\
\hline \multicolumn{7}{|c|}{$\begin{array}{ll}\text { Presudo } \mathrm{R}^{2} & 0.0484\end{array}$} \\
\hline \multicolumn{7}{|c|}{ Prob $>$ chi $2 \quad 0.0000$} \\
\hline \multicolumn{7}{|c|}{ Wald chi2(11) $\quad 42.02$} \\
\hline
\end{tabular}

Table no. (7) proposes the logistic regression results examining the potential effects of risk factors relating to the opportunity

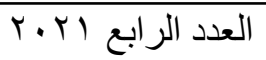


dimension of the fraud triangle model on the engagement in financial fraud. In model (2), Pseudo R2 is (0.027) which is relatively low and the p-value for model (2) is significant at (0.0292). Audit independence (AUDIND) is statistically significant and in the predicted sign with financial statement frauds. This result is consistent with Beasley et al. (2000), Skousen et al. (2008), and Nakashima (2017). This finding indicated that independence of audit committees and other corporate boards are effective internal corporate governance mechanisms to oversight a firm's internal control system and its financial reporting process the matter that reluctant the tendency toward engaging in financial statements frauds.

Board independence (BIND) and CEO duality (DUAL) are significantly associated with financial statement frauds (FRAUD), however, in the opposite direction to the predicted sign expected in Skousen et al. (2008), Aghghaleh et al. (2014), and Nakashima (2017), suggesting that fraudulent firms have higher percentage of external directors in corporate boards and their CEO possesses less power than non-fraudulent firms. Board size (BSIZE), managerial ownership (MGOWN), institutional ownership (ISOWN), and inventory to total assets (INVTA) are statistically insignificant. These findings are inconsistent to what was suggested in Beasley (1996) and Skousen et al. (2008), however, in line with Nakashima (2017). These results could be related to the fact that the quality of corporate governance 
Can Fraud Triangle Model Predict Fraudulent Financial Statements?

Dr/Shaimaa Fikry Mehanna \& Dr/Mohammed Mahmoud Soliman

practices and the adherence to its regulation and standards in developing markets are not like their counterparts in developed markets, the matter that affected the significance of the results.

\section{Table (7)}

Logistic regression results for model (2) opportunity variables

\begin{tabular}{|c|c|c|c|c|c|c|}
\hline \multicolumn{7}{|c|}{$\begin{array}{c}\text { FRAUDi }=\beta 0+\beta 1 \text { INBOD } \mathrm{i}+\beta 2 \text { BSIZ } \mathrm{i}+\beta 3 \text { A DUALITY } \mathrm{i}+\beta 4 \text { INDAUD } \mathrm{i}+\beta 5 \\
\text { MAGOW } \mathrm{i}+\beta 6 \text { INSOW } \mathrm{i}+\beta 7 \text { INVTA } \mathrm{i}+\varepsilon \mathrm{i}\end{array}$} \\
\hline $\begin{array}{l}\text { Independent } \\
\text { variable }\end{array}$ & $\begin{array}{l}\text { Expected } \\
\text { Sign }\end{array}$ & Coef. & Std. Err. & $\mathrm{Z}$ & $\mathrm{P}>|\mathrm{z}|$ & VIF \\
\hline BIND & - & 0.8980729 & 0.4456682 & 2.02 & $0.044 *$ & 1.74 \\
\hline BSIZE & - & 0.2598598 & 0.6279688 & 0.41 & 0.679 & 1.45 \\
\hline DUAL & + & -0.320062 & 0.1842793 & -1.74 & $0.082 *$ & 1.12 \\
\hline AUDIND & - & -1.146602 & 0.4286107 & -2.68 & $0.007 * *$ & 1.30 \\
\hline MGOWN & - & 0.276 & 0.5947387 & 0.46 & 0.643 & 1.56 \\
\hline ISOWN & - & 0.1547257 & 0.3800498 & 0.41 & 0.684 & 2.02 \\
\hline INVTA & + & -0.005319 & 0.6097679 & -0.01 & 0.993 & 1.13 \\
\hline FSIZE & - & -0.2567046 & 0.1740506 & -1.47 & 0.140 & 1.57 \\
\hline \multicolumn{7}{|c|}{$\begin{array}{ll}\text { Presudo R2 } & 0.0277\end{array}$} \\
\hline \multicolumn{2}{|l|}{ Prob $>$ chi 2} & \multicolumn{5}{|l|}{0.0292} \\
\hline \multicolumn{2}{|l|}{ Wald chi2(14) } & \multicolumn{5}{|l|}{25.59} \\
\hline
\end{tabular}

Table no. (8) presents the logistic regression results examining the potential effects of risk factors representing managers' attitude or rationalization dimension of fraud triangle model on the engagement in financial frauds. In model (3), Pseudo R2 is (0.030) which is relatively low and the p-value for model (3) is significant at (0.003). Total accrual (TA) is significantly associated with financial statements frauds

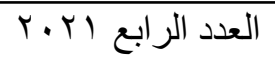$$
\text { المجلد الثاني عشر }
$$ 
Can Fraud Triangle Model Predict Fraudulent Financial Statements?

Dr/Shaimaa Fikry Mehanna \& Dr/Mohammed Mahmoud Soliman

(FRAUD). This result is consistent with Skousen et al. (2008) and Nakashima (2017). This finding suggested that firms with higher tendency to manipulating their earnings are more likely to rationalize their fraudulent financial reporting. The quality of the external audit (BIG4) and firm size (FSIZE) had statistically insignificant association with financial statements frauds inconsistently with Suyanto (2009) and Amara et al. (2013).

\section{Table (8)}

Logistic regression results for model (3) attitude variables

\begin{tabular}{|c|c|c|c|c|c|c|}
\hline \multicolumn{7}{|c|}{ FRAUDi $=\beta 0+\beta 1$ BIG4 i $+\beta 2$ TAC $\mathrm{i}+\beta 3$ SIZEi $+\varepsilon i$} \\
\hline $\begin{array}{l}\text { Independent } \\
\text { variable }\end{array}$ & $\begin{array}{c}\text { Expected } \\
\text { Sign }\end{array}$ & Coef. & Std. Err. & $\mathrm{Z}$ & $\mathrm{P}>|\mathrm{z}|$ & VIF \\
\hline BIG4 & - & 0.2777021 & 0.1767807 & 1.57 & 0.116 & 1.14 \\
\hline TAC & + & 3.018718 & 0.8440532 & 3.58 & $0.000 * * *$ & 1.02 \\
\hline FSIZE & - & -0.1496704 & 0.15139 & -0.99 & 0.323 & 1.15 \\
\hline \multicolumn{7}{|c|}{$\begin{array}{ll}\text { Presudo R2 } & 0.0304\end{array}$} \\
\hline \multicolumn{2}{|l|}{ Prob > chi 2} & 0.0030 & & & & \\
\hline \multicolumn{2}{|l|}{ Wald chi2(9) } & 24.96 & & & & \\
\hline
\end{tabular}

Table no. (9) proposes the logistic regression results examining the potential effects of risk factors representing the three dimensions of fraud triangle model- pressure, opportunity, and rationalization- on the engagement in financial frauds. In model (4), Pseudo R2 is (0.091) which is relatively low and the p-value for model (4) is significant at (0.000).

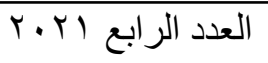


In model 4, financial leverage (LEV), capital turnover (SALTA), audit independence (AUDIND), total accruals (TA), and firm size (FSIZE) are statistically significant in the predicted sign with fraudulent financial statements (FRAUD). These findings suggested that fraudulent firms have higher leverage ratio, higher percentage of non-executives in their audit committees, higher tendency toward manipulating their earnings, and less competitive than non-fraud firms in utilizing their assets to generate sales. These finding are consistent with what was suggested in Pearsons (1995), Beasley et al. (2000), Skousen et al. (2008), Lou and Wang (2009), Aghghaleh et al. (2014), and Nakashima (2017).

Firm profitability (PROFT), board independence (BIND), CEO duality (DUAL), and the quality of the external audit (BIG4) are statistically significant, however, in the opposite direction to the predicted sign with fraudulent financial statements. These findings are inconsistent with Pearsons (1995), Suyanto (2009). These findings suggested that fraudulent firms have higher profitability ratio, have higher percentage of external directors in corporate boards and their CEO possesses less power than non-fraudulent firms, and are likely to engage with big four audit firms which are inconsistent with prior literature.

Firm liquidity (LIQ) has insignificant with financial statements frauds in line with Amara et al. (2013) and Fitri et al. (2019) that found an insignificant association between firm

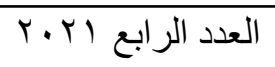

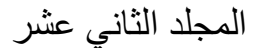


Can Fraud Triangle Model Predict Fraudulent Financial Statements?

Dr/Shaimaa Fikry Mehanna \& Dr/Mohammed Mahmoud Soliman

liquidity (LIQ) and financial frauds (FRAUD). Board size (BSIZE), managerial ownership (MGOWN), institutional ownership (ISOWN), and inventory to total assets (INVTA) are statistically insignificant with fraudulent financial statements. These findings are inconsistent to what was suggested in Beasley (1996), Skousen et al. (2008), and Suyanto (2009).

\section{Table (9)}

\section{Logistic regression results for model (4)}

\begin{tabular}{|c|c|c|c|c|c|c|}
\hline \multicolumn{7}{|c|}{$\begin{array}{c}\text { FRAUDi }=\beta 0+\beta 1 \text { LEV } \mathrm{i}+\beta 2 \text { LIQ } \mathrm{i}+\beta 3 \text { PROFTA } \mathrm{i}+\beta 4 \text { SALTA } \mathrm{i}+\beta 5 \text { INBOD } \mathrm{i}+\beta 6 \\
\text { BSIZ } \mathrm{i}+\beta 7 \text { A DUALITY } \mathrm{i}+\beta 8 \text { INDAUD } \mathrm{i}+\beta 9 \text { MAGOW } \mathrm{i}+\beta 10 \text { INSOW } \mathrm{i}+\beta 11 \\
\text { INVTA } \mathrm{i}+\beta 12 \text { BIG4 } \mathrm{i}+\beta 13 \text { TAC } \mathrm{i}+\beta 14 \text { SIZE } i+\varepsilon \mathrm{i}\end{array}$} \\
\hline $\begin{array}{l}\text { Independent } \\
\text { variable }\end{array}$ & $\begin{array}{l}\text { Expected } \\
\text { Sign }\end{array}$ & Coef. & Std. Err. & $\mathrm{Z}$ & $\mathrm{P}>|\mathrm{z}|$ & VIF \\
\hline LEV & + & 0.9679289 & 0.4193802 & 2.31 & $0.021 * *$ & 1.71 \\
\hline LIQ & - & -0.020257 & 0.0163694 & -1.24 & 0.216 & 1.26 \\
\hline PROF & - & 5.758883 & 1.087508 & 5.30 & $0.000 * * *$ & 1.64 \\
\hline SALTA & - & -0.4614824 & 0.1606932 & -2.87 & $0.004 * *$ & 1.39 \\
\hline BODIND & - & 1.072683 & 0.4804164 & 2.23 & $0.026 * *$ & 1.85 \\
\hline$\overline{\text { BSIZE }}$ & - & 0.2317585 & 0.7068234 & 0.33 & 0.743 & 1.58 \\
\hline DUALITY & + & -0.5232887 & 0.2031998 & -2.58 & $0.010 * *$ & 1.16 \\
\hline AUDIND & - & -2.24127 & 0.5349027 & -4.19 & $0.000 * * *$ & 1.57 \\
\hline MAGOWR & - & 0.159448 & 0.6329705 & 0.25 & 0.801 & 1.62 \\
\hline INSOWR & - & 0.1147486 & 0.4230867 & 0.27 & 0.786 & 2.19 \\
\hline INVTA & + & 0.0930666 & 0.6943388 & 0.13 & 0.893 & 1.20 \\
\hline BIG4 & - & 0.4243592 & 0.213945 & 1.98 & $0.047 *$ & 1.32 \\
\hline TAC & + & 1.703066 & 0.9602573 & 1.77 & $0.076^{*}$ & 1.16 \\
\hline FSIZE & - & -0.6830484 & 0.2183794 & -3.13 & $0.002 * *$ & 1.85 \\
\hline \multicolumn{7}{|c|}{$\begin{array}{ll}\text { Presudo R2 } & 0.0917\end{array}$} \\
\hline \multicolumn{2}{|l|}{ Prob > chi2 } & \multicolumn{5}{|l|}{0.0000} \\
\hline \multicolumn{2}{|l|}{ Wald chi2(20) } & 79.13 & & & & \\
\hline
\end{tabular}

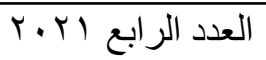




\section{CONCLUSION}

Last decades, the world was disturbed by several considerable corporate financial frauds such as Xerox, Enron, Qwest, WorldCom, and Global Crossing. These and subsequent corporate financial frauds have raised public concerns toward the reliability of financial reporting (Persons, 1995; Aghghaleh et al, 2014). The matter that has fostered the issuance of new auditing standards and regulations. In 2002, SAS No. 99 was issued by American Institute of Certified Public Accountants focusing on improving the efficiency of auditors in detecting financial frauds by assessing the fraud risk factors (Aghghaleh et al, 2014).

The fraud risk factors illustrated in fraud standards SAS No. 99 were based on fraud triangle model proposed by D. R. Cressey in 1953 (Lou and Wang, 2009; Aghghaleh et al, 2014). In this model, Cressy categorized the fraud risk factors into three groups; pressure (incentive or motivation), opportunity, and rationalization (attitude) (Lou and Wang, 2009; Aghghaleh et al, 2014). Cressy's argues that when the three risk factors -pressure, opportunity, and rationalization- combine, a great probability of engaging in financial fraud will exist (Nakashima, 2017).

This study intends to examine the three fraud risk factors pressure, opportunity, and rationalization- that presented in SAS No. 99, and empirically relates the co-existence of these factors 
to the occurrence of financial frauds through using several financial ratios that capturing firm's characteristics pertaining to the pressure and rationalization dimensions of fraud triangle model, in addition to several internal corporate governance mechanisms - capturing corporate governance practices relating to the opportunity dimension of fraud triangle model- for predicting financial statements frauds.

The results of the logistic regression analysis indicated that fraud risk factors for pressure (financial leverage and sales to total assets), for opportunity (independence of audit committee), and for rationalization (total accruals) are significantly associated to the occurrence of fraudulent financial statements. 
Can Fraud Triangle Model Predict Fraudulent Financial Statements?

Dr/Shaimaa Fikry Mehanna \& Dr/Mohammed Mahmoud Soliman

\section{REFERENCES}

Abdelsalam, O., El-Masry, A., \& Elsegini, S. (2008). Board composition, ownership structure and dividend policies in an emerging market: Further evidence from CASE 50. Managerial Finance, 34(12), 953-964.

Aghghaleh, S. F., \& Mohamed, Z. M. (2014). Fraud risk factors of fraud triangle and the likelihood of fraud occurrence: Evidence from Malaysia. Information Management and Business Review, 6(1), 1-7.

Amara, I., Amar, A. B., \& Jarboui, A. (2013). Detection of fraud in financial statements: French companies as a case study. International Journal of Academic Research in Accounting, Finance and Management Sciences, 3(3), 40-51.

Beasley, M. S. (1996). An empirical analysis of the relation between the board of director composition and financial statement fraud. Accounting review, 443-465.

Beasley, M. S., Carcello, J. V., Hermanson, D. R., \& Lapides, P. D. (2000). Fraudulent financial reporting: Consideration of industry traits and corporate governance mechanisms. Accounting horizons, 14(4), 441-454.

Beneish, M. D. (1999). The detection of earnings manipulation. Financial Analysts Journal, 55(5), 24-36.

Farber, D. B. (2005). Restoring trust after fraud: Does corporate governance matter? The accounting review, 80(2), 539-561.

Fitri, F. A., Syukur, M., \& Justisa, G. (2019). Do The Fraud Triangle Components Motivate Fraud in Indonesia? Australasian Accounting, Business and Finance Journal, 13(4), 63-72.

Kirkos, E., Spathis, C., \& Manolopoulos, Y. (2007). Data mining techniques for the detection of fraudulent financial statements. Expert systems with applications, 32(4), 995-1003.

Klein, A. (2002). Audit committee, board of director characteristics, and earnings management. Journal of accounting and economics, 33(3), 375-400.

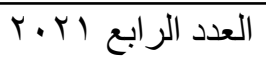

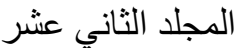


Can Fraud Triangle Model Predict Fraudulent Financial Statements?

Dr/Shaimaa Fikry Mehanna \& Dr/Mohammed Mahmoud Soliman

Latshaw, C. A., \& Elifoglu, I. H. (2003). Consideration of fraud in a financial statement audit. Bank Accounting \& Finance, 16(3), 27-33.

Lou, Y. I., \& Wang, M. L. (2009). Fraud risk factor of the fraud triangle assessing the likelihood of fraudulent financial reporting. Journal of Business \& Economics Research (JBER), 7(2).

Manurung, D. T., \& Hadian, N. (2013, November). Detection fraud of financial statement with fraud triangle. In Proceedings of 23rd International Business Research Conference (pp. 978-1).

Meiryani, M. A. A., Sudrajat, J., \& Riantono, I. E. (2020). The effect of financial target and financial stability on fraudulent financial statements. Journal of Critical Reviews, 7(6), 692-699.

Nakashima, M. (2017, November). Can The Fraud Triangle Predict Accounting Fraud? Evidence from Japan. In Unpublished manuscript presented at the 8th International Conference of The Japanese Accounting Review.

Persons, O. S. (1995). Using financial statement data to identify factors associated with fraudulent financial reporting. Journal of Applied Business Research (JABR), 11(3), 38-46.

Skousen, C. J., Smith, K. R., \& Wright, C. J. (2009). Detecting and predicting financial statement fraud: The effectiveness of the fraud triangle and SAS No. 99. In Corporate governance and firm performance. Emerald Group Publishing Limited.

Surjaatmaja, L. (2018). Detecting fraudulent financial statement using fraud triangle: capability as moderating variable. KnE Social Sciences, 945-956. Suyanto, S. (2009). Fraudulent financial statement: evidence from statement on auditing standard no. 99. Gadjah Mada International Journal of Business, 11(1), 117-144. 
Can Fraud Triangle Model Predict Fraudulent Financial Statements?

Dr/Shaimaa Fikry Mehanna \& Dr/Mohammed Mahmoud Soliman

\section{APPENDIX (1)}

\section{Food and Beverages}

\begin{tabular}{|l|}
\hline 1. National company for maize products \\
\hline 2. North Cairo Mills \\
\hline 3. Alexandria Flour Mills \\
\hline 4. Egyptian Starch \& Glucose \\
\hline 5. Middle Egypt Flour Mills \\
\hline 6. Delta Sugar \\
\hline 7. Northern Upper Egypt Development \& Agricultural Production \\
\hline 8. Ismailia Misr Poultry \\
\hline 9. Mansourah Poultry \\
\hline 10. Cairo Poultry \\
\hline 11. International Agricultural Products \\
\hline 12. Egypt for Poultry \\
\hline 13. Extracted Oils \\
\hline 14. Upper Egypt Flour Mills \\
\hline 15. Middle \& West Delta Flour Mills \\
\hline 16. South Cairo \& Giza Mills \& Bakeries \\
\hline 17. Cairo Oils \& Soap \\
\hline 18. Misr Oils \& Soap \\
\hline 19. Sharkia National Food \\
\hline 20. The Arab Dairy Products Co. Arab Dairy - Panda \\
\hline
\end{tabular}

\section{Chemicals}

21. Sidi Kerir Petrochemicals

22. Misr Chemical Industries

23. Egyptian Financial \& Industrial

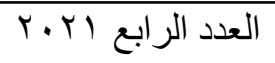


Can Fraud Triangle Model Predict Fraudulent Financial Statements?

Dr/Shaimaa Fikry Mehanna \& Dr/Mohammed Mahmoud Soliman

24. Abou Kir Fertilizers

25. Egyptian Chemical Industries (Kima)

26. Kafr El Zayat Pesticides

27. Samad Misr-EGYFERT

Basic Resources

28. Asek Company for Mining - Ascom

29. EL Ezz Aldekhela Steel - Alexandria

30. Egypt Aluminum

31. Misr National Steel - Ataqa

32. Rakta Paper Manufacturing

33. Ezz Steel

34. Egyptian Iron \& Steel

35. Arab Aluminum

\section{Industrial Goods and Services and Automobiles}

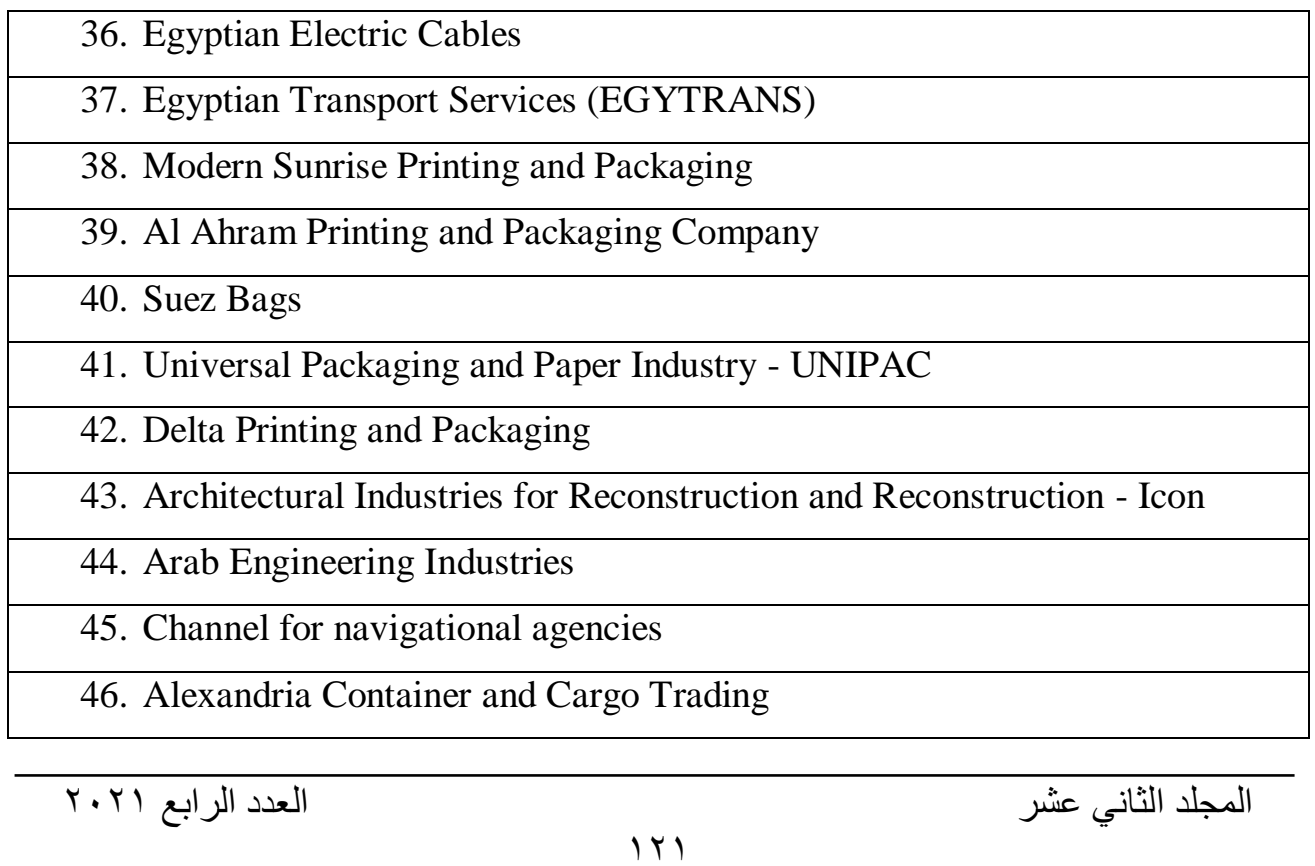


Can Fraud Triangle Model Predict Fraudulent Financial Statements?

Dr/Shaimaa Fikry Mehanna \& Dr/Mohammed Mahmoud Soliman

47. United Arab Emirates Cargo and Unloading

\section{Health care and pharmaceuticals}

48. Egyptian International Pharmaceutical Industries - IPICO

49. Memphis Pharmaceuticals and Chemical Industries

50. Nile Pharmaceuticals and Chemical Industries - Nile

51. Arab Pharmaceuticals and Chemical Industries

52. Cairo Pharmaceuticals and Chemical Industries

53. Al NOZZHA International Hospital

54. Alexandria Medical Services - New Medical Center - Alexandria

\section{Personal and Household Products}

55. Arabic Cotton Shaving Company

56. DAIS clothes

57. Nile Cotton

58. Victory for Clothing and Textiles - CABO

59. Oriental carpet weavers

60. General porcelain and Chinese products

61. Arabic and Bolvara for Spinning and Weaving

62. Alexandria Textile (Spinaplex)

63. Golden Tex for Soundings

\section{Constructions and Materials}

\begin{tabular}{|l|}
\hline 64. Robex International plastic and acrylic manufacturing \\
\hline 65. Suez Cement \\
\hline 66. National Cement \\
\hline 67. Sinai Cement \\
\hline 68. South Valley Cement \\
\hline
\end{tabular}

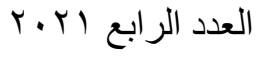


Can Fraud Triangle Model Predict Fraudulent Financial Statements?

Dr/Shaimaa Fikry Mehanna \& Dr/Mohammed Mahmoud Soliman

\begin{tabular}{|l|} 
69. Achro-Msir for fenders and metal scaffolding \\
\hline 70. Delta Construction and Development Company \\
\hline 71. Al Nasr Civil Works Company \\
\hline 72. Modern insulation materials \\
\hline 73. Giza General Contracting and Investment Properties \\
\hline 74. Egyptian Construction Industry Development (Lyft Slab Egypt) \\
\hline 75. SAMKRIT Egypt - Engineers and Contractors \\
\hline 76. Arabic valves co. \\
\hline 77. Chemical Industries - Bakken \\
\hline 78. Glory for ceramics and porcelain - Jewel \\
\hline 79. LESIKO Egypt \\
\hline 80. Arabic Ceramics - CERAMICA RIMAS \\
\hline 81. Portland Tora Cement \\
\hline 82. Egypt Cement - Qena \\
\hline 83. Egypt Beni Suaf Cement \\
\hline 84. Egypt Refrigeration and Air Conditioning Industry - MIRACO \\
\hline
\end{tabular}

\section{Real Estate}

85. October 6th for development and investment - SUDIK

86. Zahra Al Maadi Investment and Construction

87. MENA Tourism and Real Estate Investment

88. National Housing Associations

89. Sun housing and construction

90. Construction and engineering consultancy

91. Cairo Housing and Construction

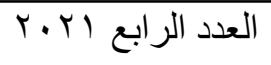


Can Fraud Triangle Model Predict Fraudulent Financial Statements?

Dr/Shaimaa Fikry Mehanna \& Dr/Mohammed Mahmoud Soliman

\begin{tabular}{|l|} 
92. United Housing and Construction \\
\hline 93. Egyptian real estate group \\
\hline 94. Real Estate for National Development Banks \\
\hline 95. Western Islamic Urban Development \\
\hline 96. New Egypt for Housing and Construction \\
\hline 97. Nasr City for Housing and Construction \\
\hline 98. Arab Land Reclamation \\
\hline 99. Cairo Investment and Development \\
\hline 100. General Land Reclamation, Development and Reconstruction \\
\hline 101. Valley com-Ambo land reclamation \\
\hline
\end{tabular}

\section{Travel and Leisure}

\begin{tabular}{|cl|}
\hline 102. & Egyptian International Tourism Projects \\
\hline 103. & Egypt's Pioneers of Tourism Investment \\
\hline 104. & PERAMISA Hotels and Tourist Villages - PERAMISA \\
\hline 105. & Orascom Development Egypt \\
\hline 106. & Egyptian Resorts \\
\hline 107. & Egypt Hotels \\
\hline 108. & Across the oceans for tourism \\
\hline 109. & Valley Tourism Investment \\
\hline 110. & Sharm Dreams Tourism Investment \\
\hline
\end{tabular}

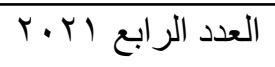

